\title{
Trace Metal Partitioning in a Nearshore Tropical Environment: Geochemistry of Carbonate Reef Flats Adjacent to Suva Harbor, Fiji Islands ${ }^{1}$
}

\author{
Fobn D. Collen, ${ }^{2,3,4}$ Jane E. Atkinson, ${ }^{3}$ and Fohn E. Patterson ${ }^{3}$
}

\begin{abstract}
Namuka Reef is a broad fringing reef flat situated immediately adjacent to the populous and heavily industrialized areas surrounding Suva Harbor, Fiji Islands. Reef flat sediments are mainly very poorly to moderately sorted carbonate gravels and sands with occasional boulders and very little silt, with terrigenous sediments limited to a narrow, nearshore strip. Bulk sediment geochemical analyses show that trace metal concentrations are generally very low across the reef flat and closely similar to pristine reef areas offshore rather than to the nearby contaminated areas within Suva Lagoon. Exceptions occur close to villages, however, where sediments are enriched in $\mathrm{Pb}$, As, and other trace metals, and possibly near wreck sites on the reef where Fe increases locally. These data together with those for major and minor oxides show that there is little or no movement of sediments from the rivers and deeper lagoon onto the carbonate reef flat even though extreme events such as tsunamis or cyclones affect the area. This indicates that the geomorphic separation of reef flats from adjacent contaminated environments is sufficient to prevent the introduction of solid contaminants. Reef flats may thus retain healthy ecosystems and provide resources to the community even though close to heavily contaminated areas.
\end{abstract}

Many coastal areas around the world have been increasingly impacted during the past century by anthropogenic contaminants that affect both water quality and the health of marine ecosystems (e.g., Wade et al. 1972, Morrisey et al. 2003, Guerra-García and García-Gómez 2005). Carbonate environments are especially susceptible because both reef growth and sediment formation depend on the health of the carbonate-producing organisms. The effects of coastal pollution are

\footnotetext{
${ }^{1}$ Manuscript accepted 14 February 2010.

${ }^{2}$ Centre for Marine Environmental and Economic Research, Victoria University of Wellington, P.O. Box 600, Wellington, New Zealand.

${ }^{3}$ School of Geography, Environment and Earth Sciences, Victoria University of Wellington, P.O. Box 600, Wellington, New Zealand.

${ }^{4}$ Corresponding author (e-mail: john.collen@vuw .ac.nz).
}

Pacific Science (2011), vol. 65, no. 1:95-107

doi: $10.2984 / 65.1 .095$

(C) 2011 by University of Hawai'i Press

All rights reserved serious in the tropical Pacific region, where many capitals are located in coastal settings and where nearshore areas are important for food gathering, recreation, and as a buffer against events such as storm surges. Pollutants here include heavy metals, which may be toxic at very low concentrations and have long-lasting effects (Clark 1992). Geochemical studies of coastal sediments can play an important role in determining the extent and source of pollution, thus aiding coastal management decisions. However, there have been few studies published on the geochemistry of nearshore carbonate sediments, and there is little published data on the spread and sequestration of natural and anthropogenic pollutants within carbonate systems.

Lagoons and associated reef flat areas are among the most threatened coastal environments. Suva, the capital of Fiji, is a rapidly growing industrial and commercial center with a population increase of $3.3 \%$ expected in the decade to 2011 (Ubitau 2006). The city occupies the Suva Peninsula that lies between Suva Harbor and Laucala Bay 


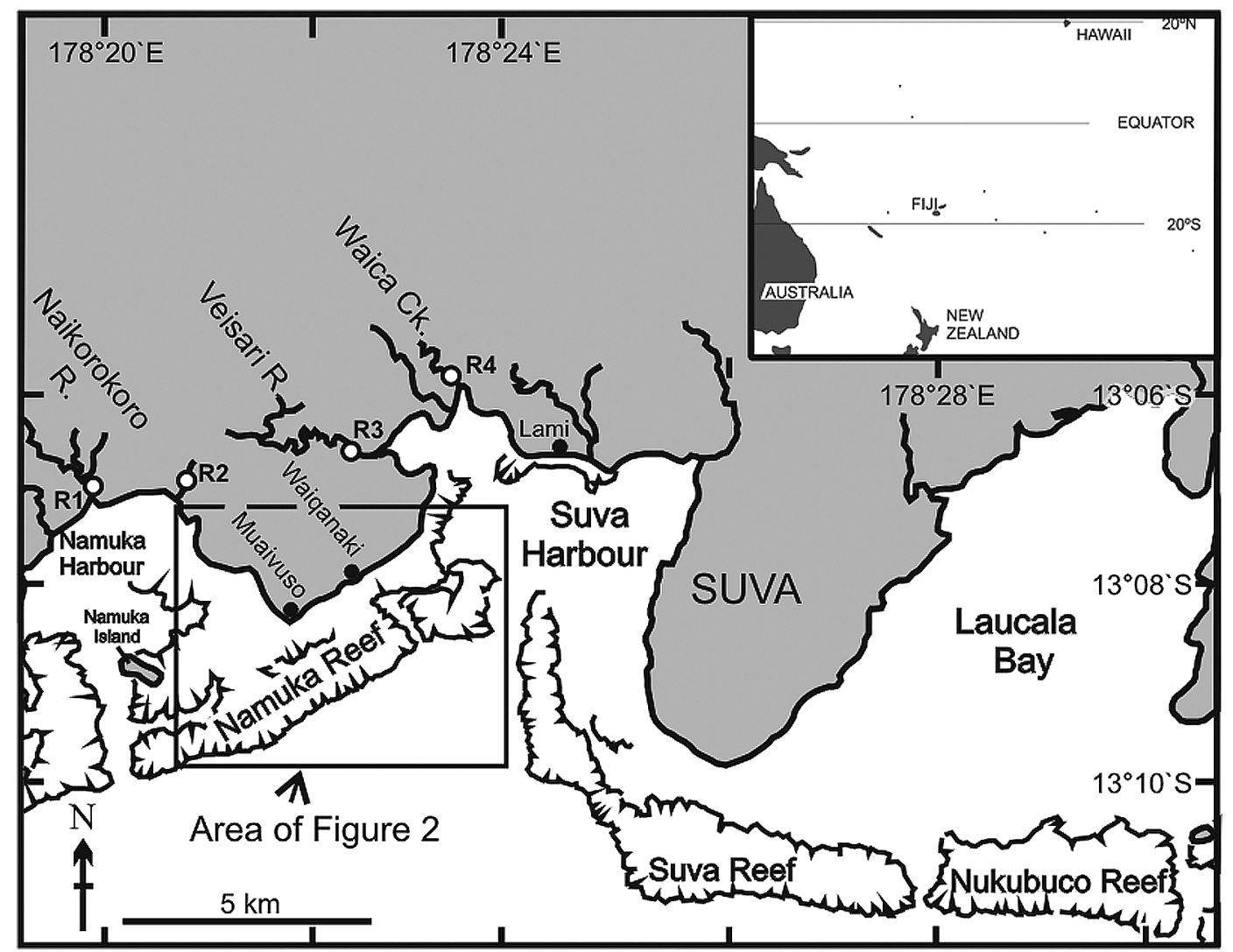

FIGURE 1. General locality map for the area around Suva, Fiji Islands.

(Figure 1), and urban development spreads west to Lami and east to Nausori. Shipbuilding and repair yards are present around western Suva Harbor (Davis et al. 1999), and other harborside industries include manufacturing, food processing, and oil storage depots (Naidu and Morrison 1994). Most of the industrial estates are on reclaimed foreshore areas (Ubitau 2006). There is an extensive and wide barrier reef system offshore, and fringing reefs extend out from the coast west of Suva Peninsula (Figure 2).

The coastal reef flats and creeks are used for washing and recreation, and support an extensive artisanal subsistence fishery (Davis et al. 1999, Brodie 2006). Development schemes have been proposed for this zone, however (Davis et al. 1999), and there is concern about the entry into Suva Harbor and
Laucala Bay of a range of pollutants (Morrison et al. 2006). Leachates from the main rubbish dump enter the northeast end of the harbor (Naidu and Morrison 1994), and other pollutants include tributyltin TBT compounds (Stewart and de Mora 1992, Davis et al. 1999), sewage (Naidu et al. 1991), and heavy metals (Dougherty 1988, Naidu and Morrison 1994, Morrison et al. 2001, Fernandez et al. 2006).

Our study reports on the major and minor oxide and trace element geochemistry of 45 samples of carbonate sediment from Namuka reef flat, a broad fringing reef flat immediately to the west of Suva Harbor (Figure 1). For comparison, we also analyzed four sediment samples from nearby rivers and one from deeper water in Suva Harbor. Other trace element studies of polluted areas of 


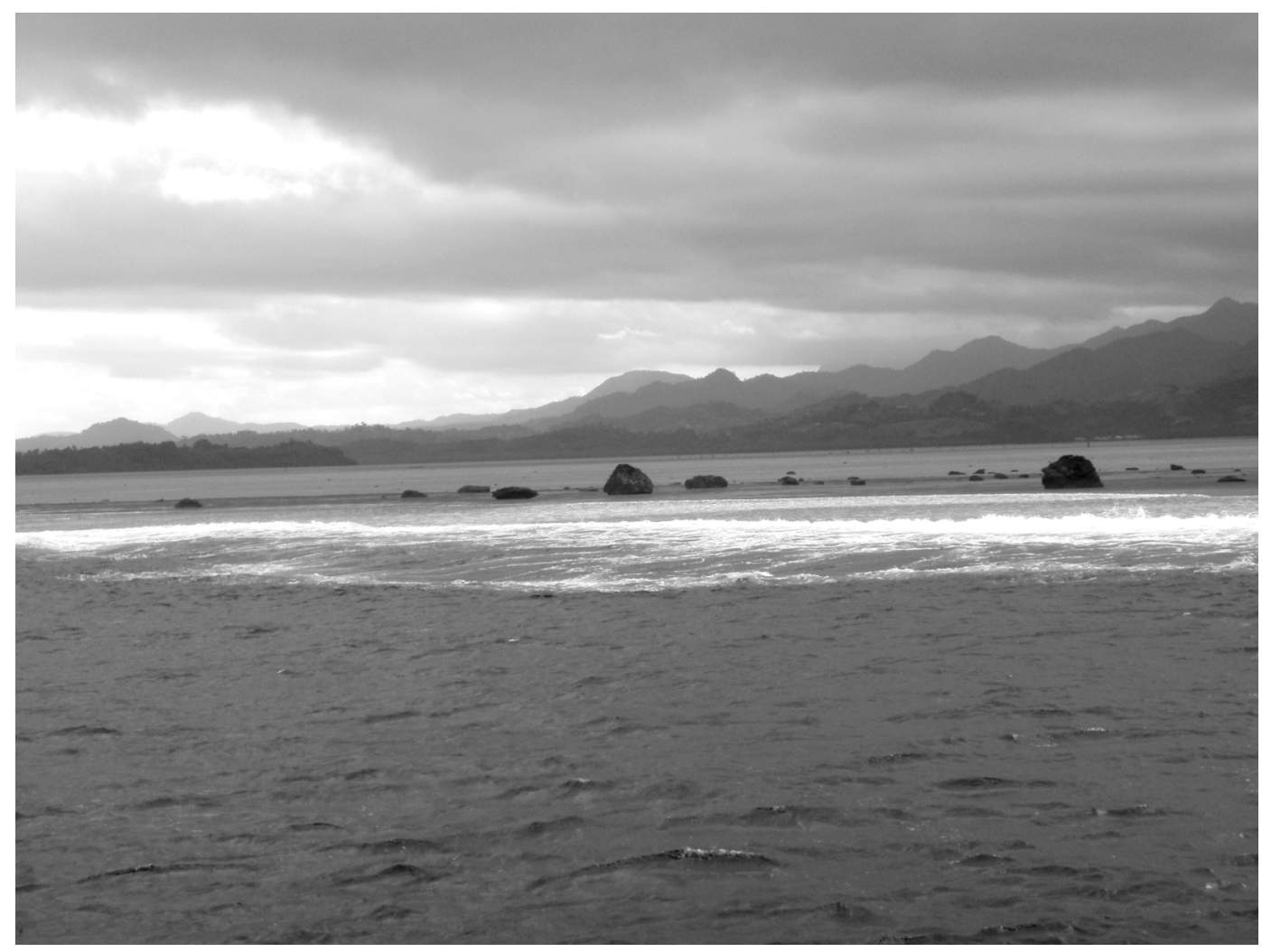

Figure 2. Namuka Reef at low tide from off Rat-tail Passage, looking west. The large boulders near the reef crest are storm and tsunami deposits. See also fig. 8 in Rahiman et al. (2007).

Suva Harbor adjacent to Namuka reef flat (Naidu and Morrison 1994) and of the pristine Great Astrolabe Lagoon to the south (Morrison et al. 1997) provide end-member baseline data (from heavily contaminated through to pristine) from which to assess $\mathrm{Na}$ muka Reef. Our data allow discussion of the connectivity between the reef flat sediments and material from rivers and the deeper lagoon, and the potential for movement of contaminants from Suva Harbor onto $\mathrm{Na}$ muka Reef.

MATERIALS AND METHODS

\section{Setting}

Namuka Reef (also known as Waiqanaki Reef) is located to the west of Suva Harbor
(Figure 1) and is part of an extensive fringing and barrier reef system along the southern Viti Levu coast. It has a maximum width of approximately $2.7 \mathrm{~km}$ with a seaward crest about $7 \mathrm{~km}$ long (Figure 2). The easternmost end of the reef complex is a natural, deepwater (50 to $70 \mathrm{~m}$ ) channel into Suva Harbor (Daveta Levu). The eastern end (Lami Reef) is separated by Rat-tail Passage, a northwesttrending $\mathrm{T}$-shaped natural passage into the reef flat that is 20 to $30 \mathrm{~m}$ deep. A discontinuous $\mathrm{S}$-shaped lagoon about $1,000 \mathrm{~m}$ by 200 $\mathrm{m}$ and with maximum depths of about $28 \mathrm{~m}$ is located approximately in the middle of the reef flat south of Muaivuso Point (Figure 3). The westernmost part of the reef is demarcated by a deepwater (30 to $40 \mathrm{~m}$ ) passage (Daveta Namuka) connecting the open ocean with Namuka Harbor. Branching off this 


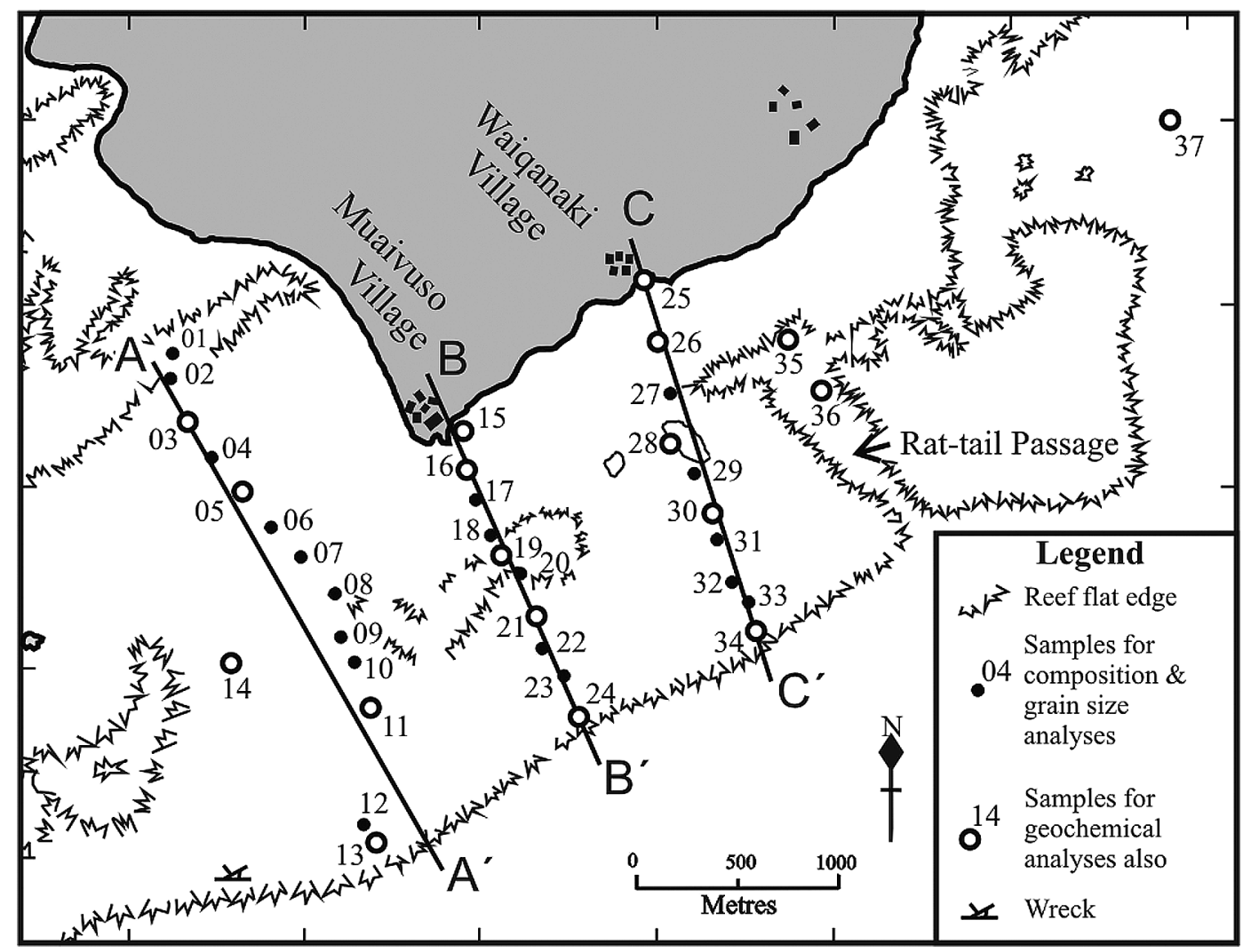

FIGURE 3. Locality map for Namuka Reef showing sample sites and transects.

passage and extending onto the western reef flat for approximately $1.5 \mathrm{~km}$ is a silled, deepwater passage that extends further as a shallow small boat passage. Farther west, $\mathrm{Na}$ muka Harbor extends for about $30 \mathrm{~km}$ as the Navua-Suva Lagoon between fringing and barrier reefs (Gussmann and Smith 2002).

Two small villages, Muaivuso and Waiqanaki, are located on the low $(5 \mathrm{~m})$ headland that juts out onto the reef flat. Mangroves occur between and on each side of the villages. Villagers use the reef on a daily basis for subsistence fishing, mostly by traditional methods from small boats. There are no obvious rivers or streams discharging directly onto the reef, although a number of small rivers discharge into both Suva and Namuka harbors (Figure 1). The only basement rock in the area is the Pliocene Suva Marl (Rodda et al. 1985, Rodda 2006) that outcrops at $\mathrm{Na}$ muka Island (Holmes 1980) and at Muaivuso Point and Waiqanaki, and forms a wave-cut platform $400 \mathrm{~m}$ wide extending out from Muaivuso Point.

Environmental data, including tidal flow, are summarized in Atkinson and Collen (2000). The area is subjected to extreme weather events, because cyclones affect the Fiji Islands at a frequency of about 10 to 12 per decade (Fiji Meteorological Service 2007). Storms affect the study area annually (Crozier et al. 1981, Howorth et al. 1981), and evidence of cyclone and storm damage is apparent all over Namuka Reef, with rubble ranging from finger-sized clasts to blocks of up to $4 \mathrm{~m}^{3}$. A block of about $1 \mathrm{~m}^{3}$ volume is said to have been thrown in from the outer reef during a cyclone in the 1980s. Reef sedi- 
ments were also affected by the tsunami that followed the 1953 Suva Earthquake, when a wave of muddy water $3 \mathrm{~m}$ high crossed the reef flat to hit the low cliffs around Muaivuso village (Houtz 1962, and eyewitness accounts from Muaivuso villagers) but did not overtop them (Rahiman et al. 2007). Village elders stated that numerous blocks of limestone along the reef crest (Figure 2) were thrown up by that tsunami and that the small boat channel changed from "neck deep to knee deep" at that time. Rahiman et al. (2007) measured blocks deposited by that event of up to $30 \mathrm{~m}^{3}$ volume and weighing up to 80 metric tons. A smaller tsunami following a 1975 earthquake in the region (Everingham 1983) had no apparent effects on the Namuka reef flats.

\section{Field Sampling and Facies}

A total of 105 bulk sediment samples was collected in February 1999 by one of us (J.E.A.) snorkeling and scuba diving along a series of transects across the reef flat and its channels, passages, and lagoons (Figure 3). Samples were collected by hand and grab, with a jet probe used to determine the thicknesses of unconsolidated sediments at some sites. Additional samples were collected for comparison by grab from Suva Harbor (Sample 37 [Figure 3]) and by hand at accessible places from four nearby rivers (Naikorokoro River, R1; an unnamed river, R2; Veisari River, R3; and Waica Creek, R4 [Figure 1]). The Waica Creek sample was collected close to Fiji Industries Ltd. cement factory, as a site likely to have abnormal carbonate content. The samples from the rivers and harbor were intended to provide data from mixed carbonate-terrigenous facies for comparison with the reef flat carbonates.

To facilitate discussion of the sedimentology and geochemistry, sample data and field observations were used to delineate a series of sedimentary facies across the reef flat. Facies identifications were based on the largest component of the carbonate skeletal matter or the most obvious sedimentary feature present; a bathymetric differentiation also occurs.

\section{Textural and Geochemical Analysis}

Visual estimates of the abundances of the cobbles and coarser fractions were made in the field. Using a range of sediment splitters, 45 samples were subsampled and then dry sieved for sedimentological analysis. Compositional analyses were done on 38 of these samples by first identifying a minimum of 300 clasts from each of the $>2 \mathrm{~mm}, 1 \mathrm{~mm}$, $0.50 \mathrm{~mm}$, and $0.25 \mathrm{~mm}$ size fractions. The overall compositions of the samples were then calculated from the fraction weights.

Splits of 22 of the same samples were further selected for whole rock analysis using an automatic sequential X-ray fluorescence spectrometer (Philips PW1404) equipped with gold and Sc/Mo anode tubes. Samples were crushed in a tungsten carbide ring mill, then heated to $1,020^{\circ} \mathrm{C}$ for $2 \mathrm{hr}$ to determine loss on ignition (LOI) by conventional gravimetric analysis. For each sample, a prepared glass disk was analyzed for 10 major oxides, and an undiluted pressed powder pellet was analyzed for 19 trace elements. Replicate major and trace element analyses of a number of samples showed excellent agreement (within $5 \%$ ). LOI values added to the major and minor oxides gave totals generally within $\pm 1.0 \%$ of $100.0 \%$ (Table 1 ), indicating that the oxide determinations are accurate and reliable (Lechler and Desilets 1987).

\section{RESULTS}

The seven sedimentary facies recognized are, from the reef edge toward the shore, the Crest, Rubble, Porites, Lagoon, Acropora, Sand, and Mangrove facies, respectively (Figure 4). In general, the facies are oriented parallel to the reef crest and grade into each other without abrupt contacts. The sediments are almost entirely composed of autochthonous carbonate components and vary because of differences in wave energy, coral ecology, cementation, and bathymetry. However, terrigenous material suddenly appears in abundance (between $20 \%$ and $60 \%$ ) in the zone along the shore here termed the Mangrove facies. This is a narrow fringe of darker sediments up to $300 \mathrm{~m}$ wide that, in addition to 


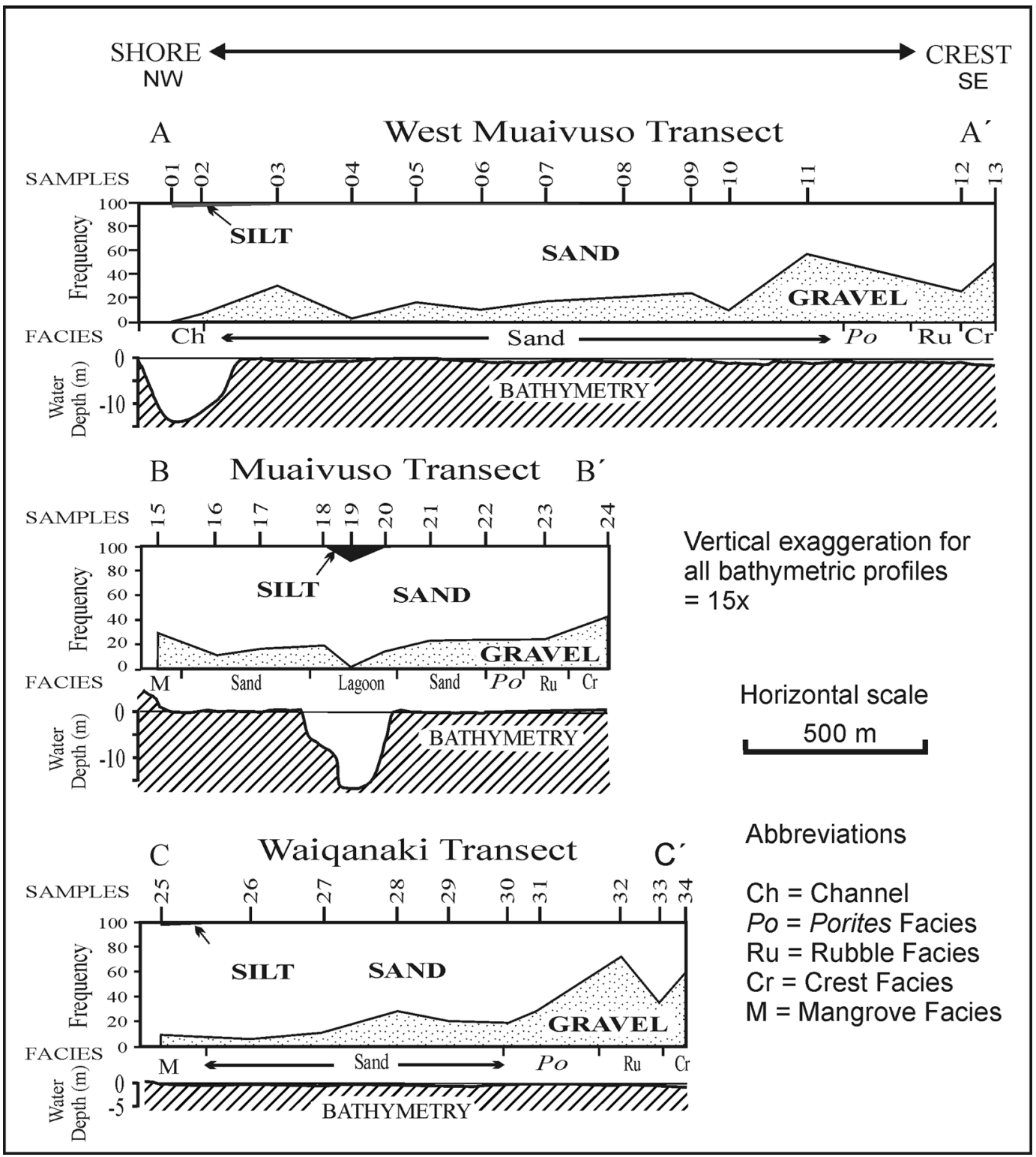

Figure 4. Bathymetry, facies, and grain size variations (frequency in percentages) along transects across Namuka Reef. Acropora facies sediments surrounding the intrareef flat lagoon in transect $\mathrm{B}-\mathrm{B}^{\prime}$ are not shown.

the carbonate clasts, contains sand-sized particles derived from the Suva Marl.

Details of the sedimentology will be presented elsewhere. However, sediments analyzed range in size from boulders to silts. Boulders were most common in the rubble and crest facies (15\% to $25 \%)$. The rest of the reef flat surface area typically had coverage of $5 \%$ to $15 \%$ cobble and boulder-sized clasts. There is very little silt-sized sediment (typically less than 1\%) in the reef flat sediments, and greater amounts (up to $15 \%$ ) 
occur only in the reef flat lagoon. Along transects, the grain size is coarsest at the reef crest and generally decreases shoreward (Figure 4). The sediments vary from very poorly to moderately sorted, with most $(76 \%)$ being poorly sorted.

Although the exact composition varies between samples and between facies, an average for the 38 samples analyzed shows that most sediment is composed of carbonate clasts derived mainly from coral (49\%), calcareous red and green algae (22\%), mollusks (16\%), and foraminifera (9\%). The remaining biota supply some $2 \%$ of the total, and, overall, terrigenous material accounts for another $3 \%$.

Most reef flat sediments have very similar major element abundances, with the expected high $\mathrm{CaO}$, low $\mathrm{SiO}_{2}$, and relatively even (2.1\% to $3.8 \%) \mathrm{MgO}$ values (Table 1 ). Most reef flat samples show minimal (less than 1\%) $\mathrm{Si}, \mathrm{Al}$, and $\mathrm{Fe}$ oxides. In contrast, samples from the nearshore Mangrove facies $(15,25)$, Suva Harbor (37), and the three westernmost river samples (R1-R3) show higher $\mathrm{SiO}_{2}$, $\mathrm{Al}_{2} \mathrm{O}_{3}, \mathrm{Fe}_{2} \mathrm{O}_{3}, \mathrm{TiO}_{2}, \mathrm{MnO}$, and $\mathrm{K}_{2} \mathrm{O}$ values. The sample from Suva Harbor also shows a high content of $\mathrm{Si}, \mathrm{Al}$, and $\mathrm{Fe}$ oxides. Most minor oxides are present in very low abundances in most samples. Noticeable peaks of $\mathrm{TiO}_{2}(0.3 \%), \mathrm{K}_{2} \mathrm{O}(0.93 \%)$, and $\mathrm{P}_{2} \mathrm{O}_{5}$ $(0.25 \%)$ occur in a Mangrove facies sample (15) adjacent to Muaivuso village (Table 1).

Trace element concentrations are given in Table 2. Many samples had trace metal levels too low to be determined by X-ray fluorescence. Strontium was abundant, zirconium was common, and the remaining elements were mostly in low concentration in carbonate-dominated samples from the reef flats. As with the major oxides, higher values of the metals occur in the shoreline Mangrove facies samples (especially sample 15

TABLE 1

Major and Minor Oxide Concentrations in $\mu \mathrm{g} \mathrm{g} \mathrm{g}^{-1}$

\begin{tabular}{|c|c|c|c|c|c|c|c|c|c|c|c|c|c|}
\hline Sample & Site ${ }^{a}$ & $\mathrm{SiO}_{2}$ & $\mathrm{Al}_{2} \mathrm{O}_{3}$ & $\mathrm{Fe}_{2} \mathrm{O}_{3}$ & $\mathrm{MgO}$ & $\mathrm{CaO}$ & $\mathrm{Na}_{2} \mathrm{O}$ & $\mathrm{TiO}_{2}$ & $\mathrm{MnO}$ & $\mathrm{K}_{2} \mathrm{O}$ & $\mathrm{P}_{2} \mathrm{O}_{5}$ & LOI & Total \% \\
\hline 03 & $\varangle$ & 0.33 & 0.15 & 0.21 & 2.62 & 49.97 & 1.06 & 0.02 & 0.01 & 0.06 & nd & 44.73 & 99.16 \\
\hline 05 & $\ddot{U}$ & 0.25 & 0.14 & 0.07 & 2.91 & 48.98 & 1.00 & 0.01 & 0.01 & 0.04 & 0.04 & 44.85 & 98.30 \\
\hline 11 & 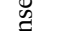 & 0.33 & 0.17 & 0.08 & 3.03 & 49.92 & 1.05 & 0.01 & 0.01 & 0.06 & 0.04 & 45.00 & 99.70 \\
\hline 13 & $\bar{\pi}$ & 0.80 & 0.21 & 1.38 & 3.09 & 48.55 & 0.93 & 0.01 & 0.01 & 0.07 & 0.05 & 44.06 & 99.16 \\
\hline 14 & $H$ & 0.16 & 0.09 & 0.07 & 3.02 & 49.57 & 1.16 & 0.01 & 0.01 & 0.05 & 0.04 & 44.40 & 98.58 \\
\hline 15 & $\infty$ & 21.83 & 6.40 & 4.59 & 5.36 & 30.49 & 1.75 & 0.33 & 0.06 & 0.93 & 0.25 & 27.42 & 99.41 \\
\hline 16 & $\ddot{U}$ & 0.43 & 0.21 & 0.21 & 3.28 & 48.27 & 1.17 & 0.01 & 0.01 & 0.06 & 0.06 & 44.75 & 98.25 \\
\hline 19 & $\overline{\mathscr{g}}$ & 0.79 & 0.28 & 0.16 & 2.97 & 48.45 & 1.43 & 0.01 & 0.01 & 0.07 & 0.05 & 44.82 & 99.04 \\
\hline 21 & Еี & 0.21 & 0.11 & 0.14 & 3.03 & 49.82 & 1.00 & 0.01 & 0.01 & 0.05 & 0.04 & 44.97 & 99.39 \\
\hline 24 & $H$ & 0.42 & 0.20 & 0.19 & 2.70 & 48.98 & 1.46 & 0.01 & 0.01 & 0.06 & 0.04 & 45.06 & 99.13 \\
\hline 25 & $U$ & 4.67 & 1.42 & 1.23 & 3.83 & 45.08 & 1.05 & 0.07 & 0.01 & 0.12 & 0.08 & 41.89 & 99.45 \\
\hline 26 & $\breve{U}$ & 0.51 & 0.21 & 0.15 & 3.30 & 49.54 & 0.74 & 0.01 & 0.01 & 0.04 & 0.06 & 44.64 & 99.21 \\
\hline 28 & $\mathscr{\mathscr { E }}$ & 0.29 & 0.15 & 0.10 & 3.60 & 49.11 & 1.04 & 0.01 & 0.01 & 0.06 & 0.07 & 45.08 & 99.52 \\
\hline 30 & Еี & 0.31 & 0.15 & 0.09 & 3.52 & 48.91 & 1.27 & 0.01 & 0.01 & 0.06 & 0.05 & 44.89 & 99.27 \\
\hline 34 & $H$ & 0.37 & 0.21 & 0.11 & 3.12 & 49.63 & 0.80 & 0.01 & 0.01 & 0.07 & 0.05 & 44.71 & 99.09 \\
\hline 35 & & 0.31 & 0.16 & 0.12 & 3.40 & 49.15 & 1.08 & 0.01 & 0.01 & 0.05 & 0.06 & 44.92 & 99.27 \\
\hline 36 & RTP & 0.57 & 0.27 & 0.19 & 2.86 & 49.09 & 1.14 & 0.01 & 0.01 & 0.05 & 0.05 & 44.59 & 98.83 \\
\hline 37 & $\mathrm{SH}$ & 25.06 & 10.97 & 5.15 & 3.51 & 20.64 & 2.84 & 0.40 & 0.07 & 0.48 & 0.14 & 30.47 & 99.73 \\
\hline $\mathrm{R} 1$ & & 55.23 & 16.74 & 9.11 & 2.46 & 1.11 & 1.66 & 0.71 & 0.09 & 0.67 & 0.10 & 12.56 & 100.44 \\
\hline $\mathrm{R} 2$ & $\dot{\bar{\nu}}$ & 46.24 & 16.55 & 8.03 & 2.06 & 1.56 & 3.34 & 0.69 & 0.09 & 0.63 & 0.08 & 20.83 & 100.10 \\
\hline R3 & 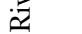 & 50.40 & 18.12 & 10.22 & 2.28 & 0.96 & 1.31 & 0.79 & 0.09 & 0.61 & 0.07 & 15.86 & 100.71 \\
\hline $\mathrm{R} 4$ & & 8.16 & 2.67 & 1.02 & 3.37 & 39.63 & 1.10 & 0.11 & 0.02 & 0.20 & 0.06 & 42.13 & 98.74 \\
\hline
\end{tabular}

${ }^{a}$ RTP, Rat-tail Passage; SH, Suva Harbor. 
TABLE 2

Trace Element Concentrations in $\mu \mathrm{g} \mathrm{g}^{-1}$

\begin{tabular}{|c|c|c|c|c|c|c|c|c|c|c|c|c|c|c|c|c|c|c|c|c|}
\hline Sample & Site ${ }^{a}$ & $\mathrm{Y}$ & $\mathrm{Sr}$ & $\mathrm{Th}$ & $\mathrm{Pb}$ & $\mathrm{Ga}$ & $\mathrm{U}$ & $\mathrm{Rb}$ & As & $\mathrm{Sc}$ & $\mathrm{V}$ & $\mathrm{Cr}$ & $\mathrm{Ba}$ & $\mathrm{La}$ & $\mathrm{Ce}$ & $\mathrm{Ni}$ & $\mathrm{Cu}$ & $\mathrm{Zn}$ & $\mathrm{Zr}$ & $\mathrm{Nb}$ \\
\hline 03 & $\varangle$ & nd & 5,030 & 0.3 & nd & 3.5 & nd & nd & 0.2 & nd & 4.9 & nd & 7.3 & nd & nd & nd & 16.4 & 1.3 & 11.8 & 0.2 \\
\hline 05 & $\tilde{u}$ & nd & 4,956 & nd & nd & 2.7 & nd & nd & nd & nd & 3.1 & nd & 6.1 & 1.1 & nd & nd & 16.1 & 1.4 & 108.7 & 0.4 \\
\hline 11 & $\mathscr{\mathscr { y }}$ & nd & 4,405 & 0.3 & nd & 1.3 & nd & nd & nd & 1.2 & 3.0 & nd & 3.1 & nd & nd & nd & 14.4 & 1.0 & 86.2 & 0.1 \\
\hline 13 & \# & nd & 4,590 & 0.5 & nd & 2.0 & nd & 0.3 & 0.1 & nd & 3.7 & nd & 5.5 & nd & nd & nd & 15.8 & 2.7 & 95.6 & 0.6 \\
\hline 14 & 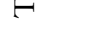 & nd & 4,394 & 0.8 & 8.4 & 2.1 & nd & nd & 5.7 & nd & 6.7 & 1.9 & 9.0 & 1.0 & nd & nd & 16.0 & 9.1 & 92.9 & 0.1 \\
\hline 15 & $\infty$ & nd & 2,524 & 1.7 & 8.5 & 9.6 & 0.9 & 13.3 & 17.0 & 16.5 & 115.6 & 63.4 & 213.1 & 9.6 & 24.9 & 11.1 & 46.9 & 82.1 & 74.2 & 2.4 \\
\hline 16 & $\ddot{U}$ & nd & 4,443 & nd & nd & 2.4 & 1.5 & 1.2 & nd & 2.2 & 5.0 & nd & 7.4 & nd & nd & nd & 18.3 & 1.3 & 95.3 & 0.1 \\
\hline 19 & שू & nd & 4,610 & 1.9 & nd & 3.4 & nd & 0.7 & nd & 1.2 & 1.4 & 2.6 & 7.6 & 0.4 & nd & nd & 14.6 & 4.0 & 94.3 & 2.1 \\
\hline 21 & 苛 & nd & 4,687 & nd & nd & 1.1 & nd & 0.5 & nd & nd & 3.7 & 0.6 & 6.3 & nd & nd & nd & 18.9 & 4.3 & 100.2 & 0.1 \\
\hline 24 & & nd & 4,574 & 0.8 & nd & 1.7 & nd & nd & 0.6 & 1.3 & 3.4 & nd & 3.9 & 1.7 & nd & nd & 16.4 & 4.3 & 92.9 & 0.6 \\
\hline 25 & $u$ & nd & 3,281 & nd & nd & 3.4 & 0.6 & 1.9 & 7.3 & 4.1 & 32.9 & 23.6 & 32.8 & 3.4 & 0.6 & 0.6 & 17.4 & 13.0 & 76.4 & nd \\
\hline 26 & $\tilde{U}$ & nd & 4,056 & 0.2 & nd & 0.5 & 0.5 & 1.0 & nd & nd & 6.1 & nd & 6.5 & 0.9 & nd & nd & 12.4 & 1.5 & 87.5 & nd \\
\hline 28 & $\ddot{\mathscr{g}}$ & nd & 4,324 & 0.5 & nd & 0.2 & nd & 0.1 & nd & nd & 3.5 & nd & 5.7 & 0.7 & nd & nd & 29.5 & 3.3 & 88.4 & 0.7 \\
\hline 30 & 苟 & nd & 4,118 & nd & nd & 1.8 & nd & 0.1 & 0.2 & 1.1 & 2.1 & nd & 7.4 & 0.6 & nd & nd & 16.7 & 2.8 & 92.6 & 0.6 \\
\hline 34 & $F$ & nd & 4,428 & nd & nd & 3.9 & nd & 0.6 & nd & nd & 3.8 & 2.4 & 5.5 & 0.6 & nd & nd & 35.5 & 14.3 & 92.9 & 0.5 \\
\hline 35 & & nd & 4,261 & 0.4 & nd & 3.4 & nd & 1.3 & 0.2 & 2.0 & 3.6 & 3.0 & 4.9 & nd & 0.1 & nd & 11.4 & 1.4 & 89.8 & 1.0 \\
\hline 36 & RTP & nd & 4,769 & 0.7 & nd & 1.1 & nd & nd & 0.4 & nd & 5.8 & 0.4 & 5.7 & 0.8 & 0.1 & 0.1 & 12.2 & 2.1 & 104.9 & 0.9 \\
\hline 37 & $\mathrm{SH}$ & 9.4 & 1,723 & 0.2 & 13.4 & 11.6 & 1.1 & 7.4 & 9.5 & 12.9 & 70.7 & 26.2 & 24.4 & 2.4 & 7.6 & 9.5 & 37.2 & 82.3 & 72.4 & 1.3 \\
\hline R1 & & 20.6 & 87 & nd & 3.8 & 18.3 & nd & 9.8 & 8.9 & 29.5 & 189.5 & 41.7 & 57.9 & 3.8 & 14.8 & 8.1 & 45.6 & 105.7 & 77.8 & 1.5 \\
\hline $\mathrm{R} 2$ & $\grave{\bar{\nu}}$ & 22.2 & 63 & 0.1 & 4.5 & 19.8 & 2.0 & 9.6 & 6.8 & 37.6 & 229.4 & 48.1 & 34.5 & 0.2 & 11.7 & 10.0 & 61.5 & 108.4 & 66.5 & 0.9 \\
\hline R3 & $\approx$ & 24.3 & 98 & 0.7 & 11.0 & 15.5 & 1.5 & 8.6 & 4.4 & 16.4 & 125.6 & 26.9 & 30.9 & 2.8 & 8.4 & 6.6 & 40.7 & 82.1 & 89.1 & 3.3 \\
\hline $\mathrm{R} 4$ & & nd & 3,086 & nd & 2.9 & 5.4 & 1.3 & 6.4 & 4.8 & 3.0 & 39.2 & 42.3 & 53.0 & 4.9 & 8.6 & 0.7 & 17.2 & 32.9 & 72.1 & 0.1 \\
\hline
\end{tabular}

${ }^{a}$ RTP, Rat-tail Passage; SH, Suva Harbor; nd, not determined. 
adjacent to Muaivuso village), the Suva Harbor samples, and the river samples. Sample 15 contains the highest values for arsenic recorded in this study, and there is also a peak of arsenic concentration associated with increased iron, zinc, and lead in sample 13 from the crest of the western reef flat.

\section{DISCUSSION}

The geochemistry of reef flat sediments can give information on the origin and transport of the carbonate clasts and, more generally, on the degree of mixing of sediments from terrigenous and biogenic sources. Trace element data, in particular, may indicate the extent of and changes to anthropogenic influences. With increased urban and industrial development around many reef flat and lagoon areas, anthropogenic pollution is an important issue with respect to human use of the resources for food, shelter, recreation, and transport (Morrison and Aalbersberg 2006). Assessing the extent of this issue and managing its consequences is hindered by the paucity of studies of reef flat sediments and especially the general lack of relevant geochemical information.

Our data show that the Namuka reef flat sediments are dominated by skeletal carbonate gravels and sands, with associated high levels of the bioaccumulated magnesium and strontium. Values for $\mathrm{MgO}$ here are similar to those reported by Morris et al. (2003) for the Nukubuco barrier reef off Laucala Bay (Figure 1) and are mainly constrained by the same processes of calcareous algal growth and encrustation. The generally very low $\mathrm{SiO}_{2}$, $\mathrm{Al}_{2} \mathrm{O}_{3}$, and $\mathrm{Fe}_{2} \mathrm{O}_{3}$ values across the Namuka reef flats indicate minimal input of terrigenous material into the reef flat sediments beyond a narrow coastal strip. This situation occurs because terrigenous material is in low supply compared with the carbonate production and/or is restricted to the nearshore zone by wave energy that mainly moves sediment across the reef flat toward the shore. In contrast, samples from the nearshore Mangrove facies $(15,25)$, Suva Harbor (37), and the three westernmost river samples (R1-R3) show higher $\mathrm{SiO}_{2}, \mathrm{Al}_{2} \mathrm{O}_{3}, \mathrm{Fe}_{2} \mathrm{O}_{3}, \mathrm{TiO}_{2}$,
$\mathrm{MnO}$, and $\mathrm{K}_{2} \mathrm{O}$ values. These results for sediments from the Mangrove facies close to Muaivuso and Waiqanaki villages are to be expected due to the presence of abundant lithic fragments derived from the outcropping Suva Marl. This rock contains up to $40 \%$ detrital clay and about $5 \%$ fine tuffaceous fragments (Rodda et al. 1985). The sample from Suva Harbor also shows a high content of $\mathrm{Si}$, $\mathrm{Al}$, and $\mathrm{Fe}$ oxides, suggesting that much of the sediment here is derived from the rivers. Three of the river samples reflect their derivation from the noncarbonate basement strata of the region, but the fourth river sample (R4, Waica Creek) shows intermediate characteristics due to the supply of carbonate residues from the adjacent cement works. We have no evidence to explain the noticeable peaks of $\mathrm{TiO}_{2}(0.3 \%), \mathrm{K}_{2} \mathrm{O}(0.93 \%)$, and $\mathrm{P}_{2} \mathrm{O}_{5}(0.25 \%)$ that occur in a Mangrove facies sample (15) adjacent to Muaivuso village (Table 1), although these may be an anthropogenic effect.

The overall low terrigenous input is important to the biological health of the reef flat because high terrigenous input is considered to have adverse effects on tropical benthic carbonate-producing organisms (e.g., Rogers 1990, Halfar et al. 2000, Heap et al. 2001). Similarly low amounts of terrigenous material occur in sediments of Nukubuco barrier reef, despite flooding of the reef by the large Rewa River being sufficient to cause greatly lowered salinities there (Morris et al. 2003).

There is no enrichment of trace elements in the sands from Rat-tail Passage or in the silty sands from the reef flat lagoon. The gravelly sand sediments of the reef Crest facies (Figure 4) show slightly elevated levels of some trace elements at two sites, notably $\mathrm{Pb}, \mathrm{As}$, and $\mathrm{Zn}$ in sample 13 , and $\mathrm{Cu}$ and $\mathrm{Zn}$ in sample 34. The values at site 13 on the western reef crest are associated with a slight increase in $\mathrm{Fe}_{2} \mathrm{O}_{3}$ levels (Table 1) and are likely related to the wrecked ship close to the sample site. The reason for the higher values farther to the northeast in sample 34 is uncertain, but they may record a similar and isolated point source of contamination, perhaps the known wreck or an unrecorded one. 
Trace elements are enriched in the Mangrove facies $(15,25)$, Suva Harbor (37), and river (R1-R4) samples. All of these have reduced or absent skeletal carbonate material and high terrigenous sediment content. High values for the Mangrove facies samples may be due to terrigenous material being moved along the shoreline by longshore drift. The sample from close to Muaivuso village (15), however, always had higher trace element concentrations than that from by Waiqanaki village (25), which suggests a local anthropogenic source for at least some of the trace metals although we have no evidence for this. Terrigenous sediments derived from the Late Eocene and younger island arc volcanics and sedimentary rocks that compose Viti Levu (Rodda 1994, 2006) are a major source of most of the trace elements in the river samples, and some may be added from unknown anthropogenic sources along the river courses. The sample from Waica Creek (R4) shows mainly lower values than the other rivers, due to dilution of the terrigenous component with carbonate from the cement works. Major element values for the Suva Harbor sample analyzed here (37) indicate approximately equal amounts of carbonate and terrigenous sediment. The trace elements present are thus derived both from river sediments and from point sources of anthropogenic pollution around the harbor. Values for $\mathrm{Cu}, \mathrm{Pb}$, and $\mathrm{Zn}$ in particular (Table 2) are higher than those for the river samples analyzed here and thus likely reflect an anthropogenic source. Although analyzed by a different technique, the lower values than those reported by Naidu and Morrison (1994) for sites closer to point sources of pollution reflect the position of our sample farther from these sources together with the dilution by carbonate sediment. For Suva Lagoon, high concentrations of metals of concern occur in "hot spots" near the shore (Naidu and Morrison 1994, Gangaiya et al. 2001, Fernandez et al. 2006), and the proportion of carbonate generally increases seaward (Morrison et al. 2006).

Figure 5 shows a comparison of metal concentrations from the data presented in this article for Namuka Reef with information from the adjacent Suva Harbor (con- taminated) and from the Great Astrolabe Reef south of Fiji (pristine). Data for only six metals $(\mathrm{Cr}, \mathrm{Ni}, \mathrm{Cu}, \mathrm{Zn}, \mathrm{As}, \mathrm{Pb})$ are available from all sites. The Suva Harbor samples reported by Naidu and Morrison (1994) were taken from the shallow marine environment adjacent to the main rubbish dump, $3.5 \mathrm{~km}$ northeast of the eastern end of the NamukaLami reefs. Metals were shown to be moving away from the unlined dump into the marine environment (Naidu and Morrison 1994), and values for all metals averaged at least twice as high as for Namuka Reef (Figure 5). Zn was up to 20 times higher. Many samples from Namuka Reef had metal levels too low to be determined; if trace element levels for these (especially $\mathrm{Ni}, \mathrm{Cr}$, and $\mathrm{Pb}$ ) could have been determined and included in the average values, they would have further increased the contrast between the two areas.

Morrison et al. (1997) reported that trace metal analyses of samples from the Great Astrolabe Lagoon approximately $85 \mathrm{~km}$ south of Suva showed no evidence of anthropogenic pollution, although three samples close to volcanic islands showed elevated levels of some metals that they ascribed to terrigenous input. Morrison et al. (1997) regarded the Great Astrolabe Lagoon as a pristine marine environment and because of this suggested it as a site for the long-term study of trace metal contamination of the South Pacific Ocean. Overall, our results for Namuka Reef are very similar to those from the Great Astrolabe Lagoon (Figure 5, columns B, C), with all metals except $\mathrm{Pb}\left(8.5 \mu \mathrm{g} \mathrm{\textrm {g } ^ { - 1 }}\right.$ compared with $7.3 \mu \mathrm{g} \mathrm{g}^{-1}$ ) showing slightly lower concentrations at Namuka. Given the low concentrations, such differences are negligible. If samples having a clear terrigenous influence are omitted (Figure 5, columns D, $\mathrm{E})$, average trace metal concentrations at the two sites are even lower.

Trace metals entering a reef flat carbonate system may originate from the open ocean, the erosion of local noncarbonate rocks, the river transport of distal noncarbonate material, or anthropogenic pollution from urban and industrial activities. For Namuka Reef there is the additional possibility of solid materials being transported and redeposited 


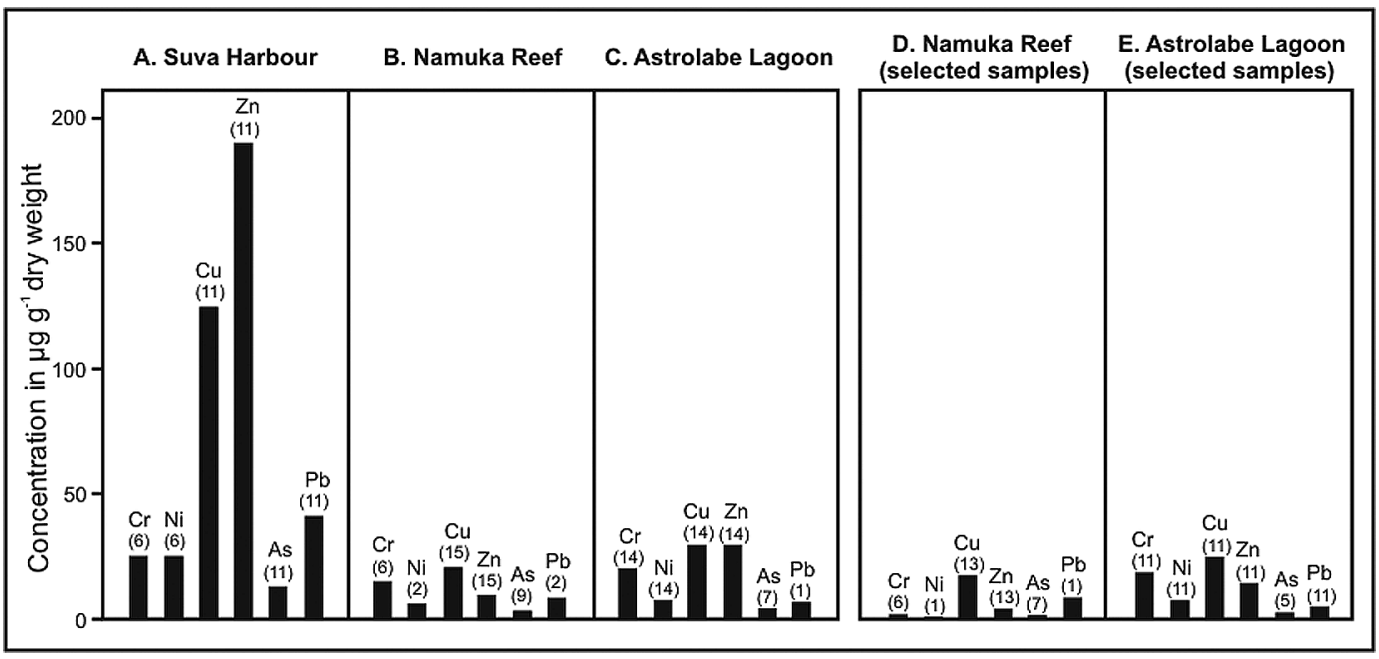

Figure 5. Comparison of some trace metal concentrations for sediments from Suva Harbor (data from Naidu and Morrison [1994]), Namuka Reef (this study), and Great Astrolabe Lagoon (data from Morrison et al. [1997]). Numbers of analyses are shown below each element. Only those data of Naidu and Morrison (1994) from the marine environment adjacent to the rubbish dump were used. Columns D and E show the average trace metal concentrations for samples with no obvious terrigenous input: samples omitted in these columns are 15 and 25 for Namuka Reef and 7, $10 \mathrm{~N}$, and 10S of Morrison et al. (1997) for Great Astrolabe Lagoon.

from adjacent deeper waters by tsunami and cyclone-induced waves. The correspondence of our data with those from a pristine carbonate environment and the contrast with data from a polluted one, however, confirm that noncarbonate materials entering Suva Harbor are not in general being transported onto the reef flat, even by extreme events. The main source of trace metals is likely to be the open ocean, as for the Great Astrolabe Lagoon, and the reef flat is thus largely uncontaminated. Exceptions are the localized areas along the shore related to human habitation and possibly areas along the reef edge where shipwreck or similar isolated events may be important contributors.

This conclusion is extremely relevant to the management of the surrounds of Suva Lagoon and to similar situations elsewhere. Many Pacific capitals are located in protected coastal waterways where the limited mixing effects of nearshore and oceanic waters allow contaminants from human activities to accumulate (Morrison 2006). Such contaminants are often concentrated in the sediments of lagoons and harbors because of transport by rivers or the locations of human activities. Our study suggests that, despite occasional extremely strong wave action sufficient to deposit limestone blocks up to $30 \mathrm{~m}^{3}$ in size onto the outer reef (Figure 2) (Rahiman et al. 2007), the physical barriers between shallow reef flats and deeper lagoons have been sufficient to prevent the spread of solid contaminants from the latter. If reef flats are protected from their own local sources of contamination, they may thus retain healthy ecosystems and continue to provide a recreational and food resource even though close to a heavily contaminated area. The wider applicability of these results, especially for the Pacific region, is hindered by the lack of modern sediment geochemical data. Many studies globally tend to concentrate on heavy metal pollution in industrialized areas (e.g., Rubio et al. 2000), and there are few studies of pristine areas for comparison. There is also limited information on soluble contaminants of reef flats, such as organochlorine compounds, for comparison, although these are likely to be more readily transported than sediments. 


\section{ACKNOWLEDGMENTS}

We thank Alf Simpson and Russell Howorth (previously director and deputy director, respectively) of the Pacific Islands Applied Geosciences Commission (SOPAC) for financial support and for making the facilities of SOPAC available to this study. Among the many helpful people at SOPAC we are particularly grateful to Robert Smith and Sekove Motuiwaca for logistic support, information, and help in the field. Marie Ferland (formerly of The University of the South Pacific) provided much assistance, and Chief Samu of Muaivuso Village kindly gave permission for work on the reef. Robert Smith provided the photograph in Figure 2. We also thank the three anonymous reviewers whose comments greatly improved the manuscript.

\section{Literature Cited}

Atkinson, J. E., and J. D. Collen. 2000. Environmental setting of Namuka Reef, Suva, Fiji Islands. SOPAC Tech. Rep. 324. Suva, Fiji.

Brodie, G. 2006. Suva Lagoon opisthobranch mollusc diversity: Associated changes in the past 20 years. Pages $72-82$ in R. J. Morrison and W. G. L. Aalbersberg, eds. At the crossroads: Science and management of the Suva Lagoon. Institute of Applied Science, The University of the South Pacific, Suva, Fiji.

Clark, R. B. 1992. Marine pollution. Clarendon Press, Oxford, United Kingdom.

Crozier, M. J., R. Howorth, and I. J. Grant. 1981. Landslide activity during cyclone Wally, Fiji: A case study of Wainitubatolu catchment. Pac. Viewpoint 22:69-88.

Davis, M. T., P. F. Newell, and N. J. Quinn. 1999. TBT contamination of an artisanal subsistence fishery in Suva Harbour, Fiji. Ocean Coastal Manage. 42:591-601.

Dougherty, G. 1988. Heavy metal concentration in bivalves from Fiji's coastal waters. Mar. Pollut. Bull. 19:81-84.

Everingham, I. B. 1983. The effects of the 16 December 1975 earthquake in Kadavu Passage, Fiji. Fiji Miner. Resour. Dep. Note BP33.
Fernandez, J.-M., G. Cadiou, B. Moreton, R. Legendre, R. Fichez, and C. Badie. 2006. Overview of the metal distribution in surface deposits and sedimentary records in Suva Lagoon. Pages 106-119 in R. J. Morrison and W. G. L. Aalbersberg, eds. At the crossroads: Science and management of the Suva Lagoon. Institute of Applied Science, The University of the South $\mathrm{Pa}$ cific, Suva, Fiji.

Fiji Meteorological Service. 2007. The climate of Fiji (http://www.met.gov.fj/documents/ Climate_of_Fiji1185488355.htm).

Gangaiya, P., J. Tabudravu, R. South, and S. Sotheeswaran. 2001. Heavy metal contamination of the Lami coastal environment, Fiji. South Pac. J. Nat. Sci. 19:24-29.

Guerra-García, J. M., and J. García-Gómez. 2005. Assessing pollution levels in sediments of a harbour with two opposing entrances: Environmental implications. J. Environ. Manage. 77:1-11.

Gussmann, O. A., and A. M. Smith. 2002. Mixed siliciclastic-skeletal carbonate lagoon sediments from a high volcanic island, Viti Levu, Fiji, Southwest Pacific. Pac. Sci. 56:169-189.

Halfar, J., L. Godinez-Orta, and J. C. Ingle. 2000. Microfacies analysis of recent carbonate environments in the southern Gulf of California, Mexico: A model for warmtemperate to subtropical carbonate formation. Palaios 15:323-342.

Heap, A. D., G. R. Dickens, and L. K. Stewart. 2001. Late Holocene sediment in Nara Inlet, central Great Barrier Reef platform, Australia: Sediment accumulation on the middle shelf of a tropical mixed clastic/ carbonate system. Mar. Geol. 176:39-54.

Holmes, R. 1980. A preliminary evaluation of the geology, engineering environment and coral sand resources associated with fringing and barrier reefs adjacent to Suva. Fiji Miner. Resour. Dep. Rep. 20.

Houtz, R. E. 1962. The 1953 Suva earthquake and tsunami. Bull. Seismol. Soc. Am. 52:1-12.

Howorth, R., M. J. Crozier, and I. J. Grant. 1981. Effects of tropical cyclone Wally in Southeast Viti Levu, Fiji, Easter 1980. Search (Syd.) 12:41-43. 
Lechler, P. J., and M. O. Desilets. 1987. A review of the use of loss on ignition as a measurement of total volatiles in wholerock analysis. Chem. Geol. 63:341-344.

Morris, M. J., J. D. Collen, R. Smith, and J. E. Patterson. 2003. Sedimentology and geochemistry of reef flat sediments, Suva, Fiji: Implications for cement manufacture. Environ. Eng. Geosci. 9:295-304.

Morrisey, D. J., S. J. Turner, G. N. Mills, R. B. Williamson, and B. E. Wise. 2003. Factors affecting the distribution of benthic macrofauna in estuaries contaminated by urban runoff. Mar. Environ. Res. 55:113-136.

Morrison, R. J. 2006. Science and management of coastal lakes and lagoons. Pages 3-14 in R. J. Morrison and W. G. L. Aalbersberg, eds. At the crossroads: Science and management of the Suva Lagoon. Institute of Applied Science, The University of the South Pacific, Suva, Fiji.

Morrison, R. J., and W. G. L. Aalbersberg. 2006. Science and management of Suva Lagoon. Pages 1-2 in R. J. Morrison and W. G. L. Aalbersberg, eds. At the crossroads: Science and management of the Suva Lagoon. Institute of Applied Science, The University of the South Pacific, Suva, Fiji.

Morrison, R. J., P. Gangaiya, S. Garimella, S. K. Singh, M. Maata, and A. Chandra. 2006. Contamination of Suva Lagoon. Pages 146-155 in R. J. Morrison and W. G. L. Aalbersberg, eds. At the crossroads: Science and management of the Suva Lagoon. Institute of Applied Science, The University of the South Pacific, Suva, Fiji.

Morrison, R. J., P. Gangaiya, M. R. Naqasima, and R. Naidu. 1997. Trace metal studies in the Great Astrolabe Lagoon, Fiji, a pristine marine environment. Mar. Pollut. Bull. 34:353-356.

Morrison, R. J., S. P. Narayan, and P. Gangaiya. 2001. Trace element studies in Laucala Bay, Suva, Fiji. Mar. Pollut. Bull. 42:397-404.

Naidu, S. D., W. G. L. Aalbersberg, J. E. Brodie, V. A. Fuavao, M. Maata, M. R. Naqasima, P. Whippy, and R. J. Morrison. 1991. Water quality studies on selected
South Pacific lagoons. United Nations Environment Programme Regional Seas Reports and Studies 136. UNEP, Nairobi.

Naidu, S. D., and R. J. Morrison. 1994. Contamination of Suva Harbour, Fiji. Mar. Pollut. Bull. 29:126-130.

Rahiman, T. I. H., J. R. Pettinga, and P. Watts. 2007. The source mechanism and numerical modelling of the 1953 Suva tsunami, Fiji. Mar. Geol. 237:55-70.

Rodda, P. 1994. Geology of Fiji. Pages 131151 in A. J. Stevenson, R. H. Herzer, and P. F. Ballance, eds. Geology and submarine resources of the Tonga-Lau-Fiji region. SOPAC Tech. Bull. 8. Suva, Fiji. 2006. Geomorphology and geology of the Suva Lagoon catchment. Pages 1532 in R. J. Morrison and W. G. L. Aalbersberg, eds. At the crossroads: Science and management of the Suva Lagoon. Institute of Applied Science, The University of the South Pacific, Suva, Fiji.

Rodda, P., I. McDougall, R. A. Cassie, D. A. Falvey, R. Todd, and J. A. Wilcoxon. 1985. Isotopic ages, magnetostratigraphy, and biostratigraphy from the early Pliocene Suva Marl, Fiji. Geol. Soc. Am. Bull. 96:529-538.

Rogers, C. S. 1990. Responses of coral reefs and reef organisms to sedimentation. Mar. Ecol. Prog. Ser. 62:185-202.

Rubio, B., M. A. Nombela, and F. Vilas. 2000. Geochemistry of major and trace elements in sediments of the Ria de Vigo (NW Spain): An assessment of metal pollution. Mar. Pollut. Bull. 40:968-980.

Stewart, C., and S. J. de Mora. 1992. Elevated tri(n-butyl)tin concentrations in shellfish and sediments from Suva Harbour, Fiji. Appl. Organomet. Chem. 6:507-512.

Ubitau, M. 2006. Urban developments in the Suva Lagoon catchment. Pages 142-145 in R. J. Morrison and W. G. L. Aalbersberg, eds. At the crossroads: Science and management of the Suva Lagoon. Institute of Applied Science, The University of the South Pacific, Suva, Fiji.

Wade, B. A., L. Antonio, and R. Mahon. 1972. Increasing organic pollution in Kingston Harbour. Mar. Pollut. Bull. 3:106-110. 
